\title{
Does the Less Developed States in Malaysia Catching-up to the Richer State of Selangor?
}

\author{
Muzafar Shah Habibullah*1, Nur Azura Sanusi², Lazim Abdullah³, Suhal Kusairi", \\ Asan Ali Golam Hassan ${ }^{5}$ \& Normi Azura Ghazali ${ }^{6}$ \\ ${ }^{1}$ Faculty of Economics and Management, Universiti Putra Malaysia, Malaysia \\ 2,4,6School of Social Development and Economics Studies, Universiti Malaysia Terengganu, \\ Malaysia \\ ${ }^{3}$ School of Informatics and Applied Mathematics, Universiti Malaysia Terengganu, Malaysia \\ ${ }^{5}$ UTM-International Business School, Universiti Teknologi Malaysia, Malaysia \\ *Corresponding author email: muzafar@upm.edu.my)
}

DOI: https://doi.org/10.37134/jcit.vol8.4.2018

\begin{abstract}
Malaysia is targeting to becoming a develop nation by 2020. However, income disparity between the developed and less developed states in Malaysia has persisted for more than 50 years without any sign of narrowing the gap in the future. Despite the various Malaysia Development Plans for the past several decades, regional disparity between states remains. Thus, the objective of the present paper is to address the question whether the less developed states, namely; Kedah, Kelantan, Pahang, Perlis, Sabah, Sarawak and Terengganu are catching-up with the more richer state of Selangor. Using annual data for the period 1970 to 2013, by employing the error-correction model our results suggests that there is cointegration and thus, imply convergence between less developed states and Selangor. Our catch-up analyses suggest that there is narrowing of disparity between Selangor and the less developed states. In this respect, the state government has an important role to play in enhancing growth by continuously providing stable economic environment for investment and other productive economic activities. This will ensure full convergence can take place at a faster rate in the future.
\end{abstract}

JEL classification: H70, O12, R12

Keywords: Income disparity; Convergence; Catch-up effect; Malaysian states

\section{INTRODUCTION}

Regional income disparity has been a never ending story for the Malaysian population. For the last forty years narrowing the regional income gap has been a daunting task faced by the Malaysian government. Roslan (2008) asserts that income inequality either between the rural and urban areas or between regions or states has been inherited since the British colonial time. During the colonial period, the British colonial policy of labor segregation tend to place the Malays in the rural areas working on agricultural farming; the Chinese in the tin ore mining areas; while the Indians work in the rubber plantations and railways. These disproportionate income earnings ultimately lead to the wide gap in income between the ethnic groups. For example, the poverty rate in 1957 for the Malays is 70.5\%, Chinese $27.4 \%$ and Indians $35.7 \%$. The statistics further show that during the same period, $60.2 \%$ of the Malays; $24.9 \%$ of the Chinese and $14.0 \%$ of the Indians work in the agriculture sector; while the manufacturing sector employed 19.6\% Malays, 72.0\% Chinese and 7.5\% Indians 
(see Leete, 2007). Furthermore, the British colonial rule promotes lop-sided development. Economic growth and development has been concentrated in the west coast of Malaya due to abundance resources such as rubber and tin-ore. Town and states such as Penang, Perak, Selangor and Negeri Sembilan were well connected by roads and railways and consequently were more developed relative to other states in the north and east of Malaya, as well as the states of Sabah and Sarawak (see also Ghani, 2014; Sundaram and Hui, 2014).

The uneven economic development as well as the wide gap in income inequalities among the ethnic groups was said to the cause of the unfortunate May thirteen incidents in 1969. In response to the racial tension, the Malaysian government has formulated the National Economic Policy (NEP) in 1970, and the NEP was incorporated in the twenty-year First Outlined Perspective Plan (1971-1990). The primary focus of the NEP for the next 20 years embedded in the Second Malaysia Plan (1971-1976) was: i) the eradication of poverty among all Malaysian, irrespective of race, through raising income levels and generating new employment opportunities, and ii) the restructuring of the Malaysian society to correct racial economic imbalances in terms of wealth, education and employment and economic opportunity (Aslam and Hassan, 2003). However, the years have passed but the structure of inequality has not changed and the NEP has not been a success story. Shamsulbahriah et al. (2013) argue that the majority of the Malaysian population is still found at the bottom of the inequality pyramid irrespective of race or gender. On the other hand, Shari (2000) found that despite there is reduction of income inequality between the urban and rural households during the 1977-1990 period, however, since 1990 income inequality has increased, both overall and with inter-ethnic as well as urban-rural income disparities.

Nevertheless, our main concern in the present study is: are the states in Malaysia converging? Economic convergence usually refers to a process in which national economies display increasing similarities in the patterns of their performance. From an economic policy point of view, the issue of convergence and divergence is very important. In a case of spontaneous convergence, this would point to the existence of market forces, which will eventually lead to similar living standards across regions. In the case of persistently large (or widening) gaps between poor and rich regions, there could be a need for economic policy measures to stimulate a catch-up process.

Thus, the purpose of the present study is to examine whether the less developed states in Malaysia have been converging, diverging or catching up to the richer state such as Selangor. In other words, we investigate whether for the past four decades regional income gaps have been narrowing between the less developed states with the richer state of Selangor. In this study, we used annual data for the period 1970 to 2013, and employing the generalised one-step error-correction model, our findings strongly support economic convergence hypothesis between the less developed states with the richer state of Selangor in Malaysia. 


\section{METHOD OF ESTIMATIONS}

\section{The Concepts of Convergence}

In this study, the time-series tests of the convergence and catching-up hypothesis for the less developed states relative to the state of Selangor are employed following Bernard and Durlauf (1995). According to Bernard and Durlauf $(1995,1996)$ convergence between two or more countries when the long-run forecasts of output differences tend to zero as the forecasting horizon tends to infinity. For instance, we can say that two economies $i$ and $j$ are converged if their per capita output $y_{i, t}$ and $y_{j, t}$ satisfy the following condition:

$$
\lim _{k \rightarrow \infty} E\left(y_{i, t+k}-y_{j, t+k} \mid I_{t}\right)=0
$$

where $I_{t}$ is the information set at time $t, y_{i, t}$ and $y_{j, t}$ are per capita output for countries $i$ and $j$ at time $t$, respectively.

This definition of convergence is relatively unambiguous for two-economy situation, but if the convergence is considered in a sample of more than two economies, it may relatively ambiguous. Further, this definition also asks whether the long run forecasts of output differences tend to zero as the forecasting horizon tends to infinity. So, if $y_{i, t+k}-$ $y_{j, t+k}$ is a mean stationary process then it is considered that the definition of convergence is satisfied and it is also required that the two countries' output must be cointegrated with a cointegrating vector $[1,-1]$. However, if the series $y_{i, t+k}-y_{j, t+k}$ contains a unit root, then we would reject the definition of convergence.

Nevertheless, if the output series do not converge, they may still have common trends and there may be a small number of stochastic trends affecting output which differ across countries (Bernard and Durlauf, 1995, 1996). In other words, series $i$ and $j$ contain a common trend if their long term forecasts of output are proportional at a fixed time $t$.

$$
\lim _{k \rightarrow \infty} E\left(y_{i, t+k}-\alpha y_{j, t+k} \mid I_{t}\right)=0
$$

Equation (2) indicates that series $i$ and $j$ have a common trend if their output series are cointegrated with cointegrating vectors $[1,-\alpha]$. In the multivariate case, Johansen's maximum likelihood analysis can be used in conjunction with the original output data for all of the countries to determine the number of cointegrating vectors (common trends).

\section{Testing for Economic Convergence}

To examine economic convergence between the less developed states in Malaysia with the richer state of Selangor, we employ the autoregressive distributed lag model approach popularised by Pesaran et al. (2001). The main purpose is to estimate the long-run models (cointegrating regression) that relate the dependent variable with its regressor. Thus, using the ARDL method we specify the following model (assuming ARDL $(1,1)$ ) as follows,

$$
g d p_{i j t}=\alpha_{0}+\beta_{1} g d p_{S E L, t}+\beta_{2} g d p_{S E L, t-1}+\beta_{3} g d p_{i j t-1}+\mu_{i j t}
$$


with $\mu_{i j t}$ is the stochastic error; $j$ is the less develop states consisting of Kedah, Kelantan, Pahang, Perlis, Sabah, Sarawak and Terengganu; $i$ is two measures of state's income - real GDP $(r g d p)$ and real GDP per capita $(r g d p p c)$; subscript $S E L$ denotes the state of Selangor; and $t$ is time periods $(t=1, \ldots, T)$.

From Equation (3) we can derive the long-run model with the following long-run coefficients,

$$
g d p_{i j t}=\theta_{0}+\theta_{1} g d p_{S E L, t}+v_{t}^{\prime}
$$

where $\theta_{0}=\alpha_{0} /\left(1-\beta_{3}\right), \theta_{1}=\left(\beta_{1}+\beta_{2}\right) /\left(1-\beta_{3}\right)$.

The error-correction model can then be specify as,

$$
\Delta g d p_{i j t}=\delta_{0}+\pi v_{t-1}^{\prime}+\delta_{1} \Delta g d p_{S E L, t}+\omega_{t}^{\prime}
$$

where the error-correction term $\left(e c m_{t-1}\right), v_{t-1}^{\prime}=g d p_{i j t-1}-\left[\theta_{0}+\theta_{1} g d p_{S E L, t-1}\right]$. The parameter $\pi$ is the error-correction parameter implying the speed of adjustment. The negative sign (between 0 and 1 ) and significant $v_{t-1}^{\prime}$ would imply cointegration, that is, long-run relationship between the less developed states and the state of Selangor.

Apart from using the error-correction term to test for cointegration, in this study we also use the bounds F-test proposed by Pesaran et al. (2001). To test for cointegration using the bounds test, we estimate the following conditional autoregressive distributed lag (ARDL) unrestricted error-correction model (UECM). For ARDL $(1,1)$ we can estimate the following ARDL-UECM model,

$$
\Delta g d p_{i j t}=\varphi_{0}+\varphi_{1} \Delta g d p_{S E L, t}+\phi_{1} g d p_{i j t-1}+\phi_{2} g d p_{S E L, t-1}+\epsilon_{t}^{\prime}
$$

where $\varphi_{0}$ is a constant term and $\epsilon_{t}^{\prime}$ is the disturbance term. According to Pesaran et al. (2001), an F-test for the joint significance of the coefficients of the lagged levels in the above Equation (6), that is the null hypothesis for no cointegration amongst variables in the equation, is $H_{0}: \phi_{1}=\phi_{2}=0$ against the alternative $H_{a}: \phi_{1} \neq \phi_{2} \neq 0$; are employed to bounds test for cointegration or the existence of a long-run relationship between the less developed states and Selangor. Rejection of the null hypothesis suggest cointegration between $g d p_{i j}$ and $g d p_{S E L}$. The asymptotic distribution of critical values is obtained for cases in which all regressors are purely $I(1)$ as well as when the regressors are purely $I(0)$ or mutually cointegrated. Because the critical value of the test depends on the order of integration of the variables, $I(d)$, where $0 \leq d \leq 1$, the test utilizes a critical range such that values exceeding the range are evidence of rejection, values less than the range are evidence of non-rejection, and values within the range are inconclusive. In other words, if the $F$ statistics exceed their respective upper critical values; we can conclude that a long-run relationship exists, without a need to know the order of integration of the regressors. If the $F$-statistics fall below the lower critical values, we cannot reject the null hypothesis of no cointegration and estimation can continue assuming no long-run relationship. If the $F$ statistics falls between the two bounds, the result is inconclusive. As such one needs to 
know the order of the integration of the underlying variables to proceed further. For small sample size as in our case we used the critical values tabulated by Narayan (2005).

\section{Sources of Data}

The data used in this study are annual observations on states per capita gross domestic product (GDP) in constant 2005 prices. The sample covers the period 1970 to 2013. Data for states GDP at constant prices are collected from the various issues of the Five-Year Malaysia Plan and Department of Statistics Malaysia. A complete range of time-series data for states per capita real GDP were interpolated using information on time, time-squared and one-year lagged Malaysia's per capita real GDP. These states are Perlis, Kedah, Kelantan, Terengganu, Penang, Perak, Pahang, Selangor, Negeri Sembilan, Melaka, Johor, Sabah, Sarawak and Wilayah Persekutuan. Using these states data series both -real GDP and per capita real GDP, we can ranked the states' output and income for 1970, 1980, 1990, 2000 and 2010. Figure 1 shows the trends in log per capita real GDP for all fourteen states in Malaysia. On one extreme we have Wilayah Persekutuan being having higher income per capita while on the extreme we have Kelantan being the lowest income per capita.

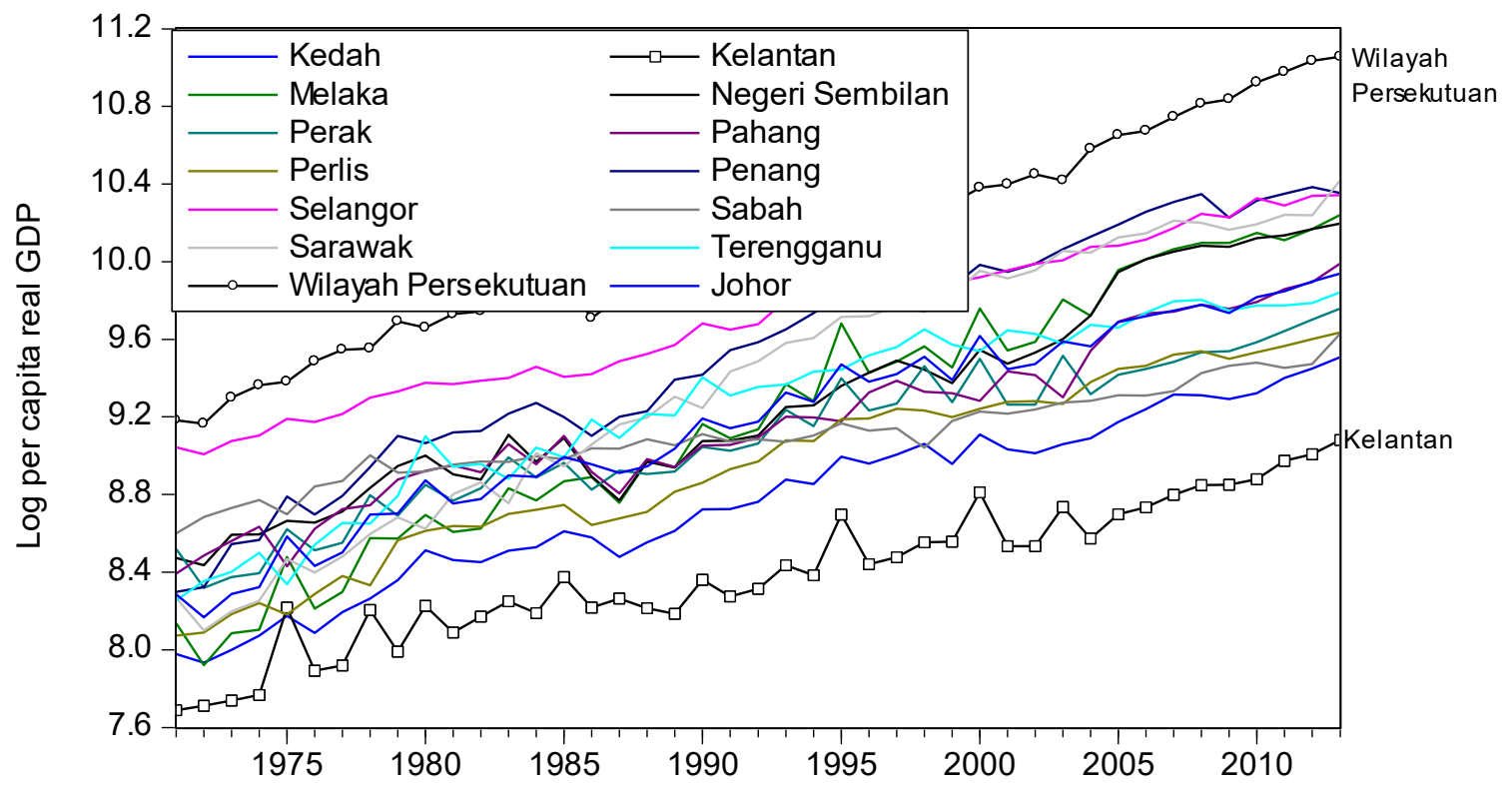

Figure 1. Trends in log per capita real GDP for all states in Malaysia

Results on ranking states by their real GDP and per capita real GDP are presented in Table 1. In Panel A, we can observe that the state of Selangor has been the richest state in Malaysia for the last four decades. This is followed by Wilayah Persekutuan, and surprisingly Sarawak is in the third place. Sarawak has been the third richest state in Malaysia for the last decade or more. On the other hand, Panel B suggests that in terms of per capita income, the state of Selangor is second to Wilayah Persekutuan, except in the year 2000 that Selangor ranked fourth after Penang and Sarawak. Among the developed states, Perak has been falling behind for the last thirty years, and is the fifth poorest states in Malaysia. Other interesting observations are the states of Sabah and Sarawak. Sabah has been the third richest state in 1970; however, for the last decades or more, Sabah has been 
lagging behind and placing her as the third poorest state in Malaysia. Sarawak on the other hand, has an amazing economic performance, catching-up and position herself as the fourth richest state in Malaysia after Wilayah Persekutuan, Selangor and Penang. In this study, throughout the analysis all variables were transformed into natural logarithm.

Table 1. States' ranking by real GDP and per capita real GDP, 1970-2010

\begin{tabular}{|c|c|c|c|c|c|}
\hline States & 1970 & 1980 & 1990 & 2000 & 2010 \\
\hline \multicolumn{6}{|l|}{ Panel A: Ranking by real GDP: } \\
\hline Kedah & 8 & 9 & 10 & 8 & 10 \\
\hline Kelantan & 13 & 12 & 13 & 13 & 13 \\
\hline Pahang & 10 & 8 & 9 & 9 & 8 \\
\hline Perlis & 14 & 14 & 14 & 14 & 14 \\
\hline Sabah & 6 & 6 & 6 & 7 & 6 \\
\hline Sarawak & 5 & 7 & 4 & 3 & 3 \\
\hline Terengganu & 11 & 10 & 8 & 10 & 12 \\
\hline \multicolumn{6}{|l|}{ Developed states: } \\
\hline Johor & 4 & 4 & 3 & 4 & 4 \\
\hline Melaka & 12 & 13 & 12 & 12 & 11 \\
\hline Negeri Sembilan & 9 & 11 & 11 & 11 & 9 \\
\hline Perak & 1 & 3 & 5 & 6 & 7 \\
\hline Penang & 7 & 5 & 7 & 5 & 5 \\
\hline Selangor & 2 & 1 & 1 & 1 & 1 \\
\hline Wilayah Persekutuan & 3 & 2 & 2 & 2 & 2 \\
\hline \multicolumn{6}{|c|}{$\begin{array}{l}\text { Panel B: Ranking by per capita real GDP: } \\
\text { Less developed states: }\end{array}$} \\
\hline Kedah & 13 & 13 & 13 & 13 & 13 \\
\hline Kelantan & 14 & 14 & 14 & 14 & 14 \\
\hline Pahang & 9 & 6 & 10 & 10 & 8 \\
\hline Perlis & 12 & 12 & 12 & 11 & 11 \\
\hline Sabah & 3 & 7 & 8 & 12 & 12 \\
\hline Sarawak & 7 & 11 & 5 & 3 & 4 \\
\hline Terengganu & 8 & 3 & 4 & 8 & 9 \\
\hline \multicolumn{6}{|l|}{ Developed states: } \\
\hline Johor & 10 & 8 & 6 & 6 & 7 \\
\hline Melaka & 11 & 10 & 7 & 5 & 5 \\
\hline Negeri Sembilan & 4 & 5 & 9 & 7 & 6 \\
\hline Perak & 5 & 9 & 11 & 9 & 10 \\
\hline Penang & 6 & 4 & 3 & 2 & 3 \\
\hline Selangor & 2 & 2 & 2 & 4 & 2 \\
\hline Wilayah Persekutuan & 1 & 1 & 1 & 1 & 1 \\
\hline
\end{tabular}

Notes: Authors' calculation.

Sources: Five Year Malaysia Plans and Department of Statistics Malaysia, various issues. 


\section{THE EMPIRICAL RESULTS}

The testing for cointegration or the long-run relationship requires determining the order of integration for all the variables involved in the study. Table 2 shows the result of the unit root tests using the standard unit root test procedure proposed by Dickey and Fuller (1979, 1981) for both log real GDP and log per capita real GDP for Kedah, Kelantan, Pahang, Perlis, Sabah, Sarawak, Selangor and Terengganu. In Panel A we present the unit root test results for states' real GDP while in Panel B are the states' per capita real GDP. Clearly, in all cases, the augmented Dickey-Fuller (ADF) test statistics indicate that all eight states real GDP as well as per capita real GDP are difference stationary, in other words, they are I(1) in levels. Having noted that all variables are of the same order of integration, we can proceed with the estimation of Equation (6) that is the test for cointegration.

Table 2. Results of augmented Dickey-Fuller unit root tests

\begin{tabular}{lllll}
\hline States & Level & & First-difference & \\
\cline { 2 - 5 } & Constant & Constant \& trend & Constant & Constant \& trend \\
\hline Panel A: Real GDP: & & & & \\
Kedah & & & & \\
Kelantan & $-0.007(1)$ & $-3.171(1)$ & $-8.836^{* * *}(0)$ & $-8.738^{* *}(0)$ \\
Pahang & $-1.835(2)$ & $-2.675(2)$ & $-9.616^{* * *}(1)$ & $-9.853^{* * *}(1)$ \\
Perlis & $-1.297(0)$ & $-2.983(1)$ & $-8.221^{* * *}(0)$ & $-8.282^{* * *}(0)$ \\
Sabah & $-1.196(0)$ & $-1.816(0)$ & $-7.805^{* * *}(0)$ & $-7.870^{* * *}(0)$ \\
Sarawak & $-2.591(1)$ & $-2.987(1)$ & $-7.950^{* * *}(0)$ & $-6.005^{* * *}(2)$ \\
Selangor & $-1.234(1)$ & $-1.096(1)$ & $-10.456^{* * *}(0)$ & $-10.546^{* * *}(0)$ \\
Terengganu & $-2.154(1)$ & $-1.924(1)$ & $-9.985^{* * *}(0)$ & $-10.521^{* * *}(0)$ \\
& $-2.499(1)$ & $-0.901(1)$ & $-9.726^{* * *}(0)$ & $-10.497^{* * *}(0)$ \\
Panel B: Per capita real & & & & \\
Kedah & $-0.292(0)$ & $-2.835(1)$ & $-8.530^{* * *}(0)$ & $-8.437^{* * *}(0)$ \\
Kelantan & $-1.273(2)$ & $-2.629(2)$ & $-9.555^{* * *}(1)$ & $-9.530^{* * *}(1)$ \\
Pahang & $-0.883(0)$ & $-2.917(1)$ & $-8.537^{* * *}(0)$ & $-8.440^{* * *}(0)$ \\
Perlis & $-0.914(0)$ & $-2.516(0)$ & $-7.875^{* * *}(0)$ & $-7.817^{* * *}(0)$ \\
Sabah & $-1.174(0)$ & $-2.932(1)$ & $-8.059^{* * *}(0)$ & $-7.997^{* * *}(0)$ \\
Sarawak & $-0.668(1)$ & $-1.532(1)$ & $-10.662^{* * *}(0)$ & $-10.573^{* * *}(0)$ \\
Selangor & $-1.631(1)$ & $-3.250(3)$ & $-10.709^{* * *}(0)$ & $-10.834^{* * *}(0)$ \\
Terengganu & $-2.098(1)$ & $-1.458(1)$ & $-10.234^{* * *}(0)$ & $-4.710^{* * *}(4)$ \\
\end{tabular}

Notes: Asterisk (***) denotes statistically significant at 1\% level. The calculated statistics are those computed in MacKinnon (1996). The optimal lag length in round brackets was chosen based on SC criterion.

The cointegration test results are presented in Table 3 for states real GDP and in Table 4 for states per capita real GDP. In Table 3 we observe that there is cointegration between states real GDP of Kedah, Kelantan, Pahang, Perlis, Sabah and Sarawak with Selangor from the bound F-test. On the other hand, the t-statistics of the error-correction term suggest cointegration in all less developed states with the state of Selangor. In other word, these results imply that there is convergence and/or long-run relationship between these states and the state of Selangor. The long-run elasticities in all cases is less than 1, implying that a $10 \%$ increase in Selangor's output, there will be a corresponding $7 \%$ increase in the output of Kedah, Kelantan, Pahang, Perlis, Sabah and Terengganu. 
On the other hand, in terms of per capita real GDP, results in Table 4 suggest that except for Sabah, Sarawak and Terengganu, all other states exhibit cointegration with Selangor as suggested from the bound F-test. However, as indicated by the cointegration results using the $t$-statistics of the error-correction term, all the less developed states show cointegration or exhibit long-run relationships with the state of Selangor. The long-run elasticities suggest that the states of Kedah, Pahang, Perlis, Sarawak and Terengganu will be more responsive to shocks propagated by Selangor compared to Kelantan and Sabah. For example, an increase in Selangor's income by 10\%, the income of the states of Kedah, Pahang, Perlis, Sarawak and Terengganu will increase by more than $10 \%$; while income for Kelantan and Sabah will increase by less than $10 \%$. Generally, the results suggest that there is convergence between the less developed states with the state of Selangor for the period under study.

Table 3. Estimated long-run and short-run responses of less developed states to richer state Selangor, in real GDP

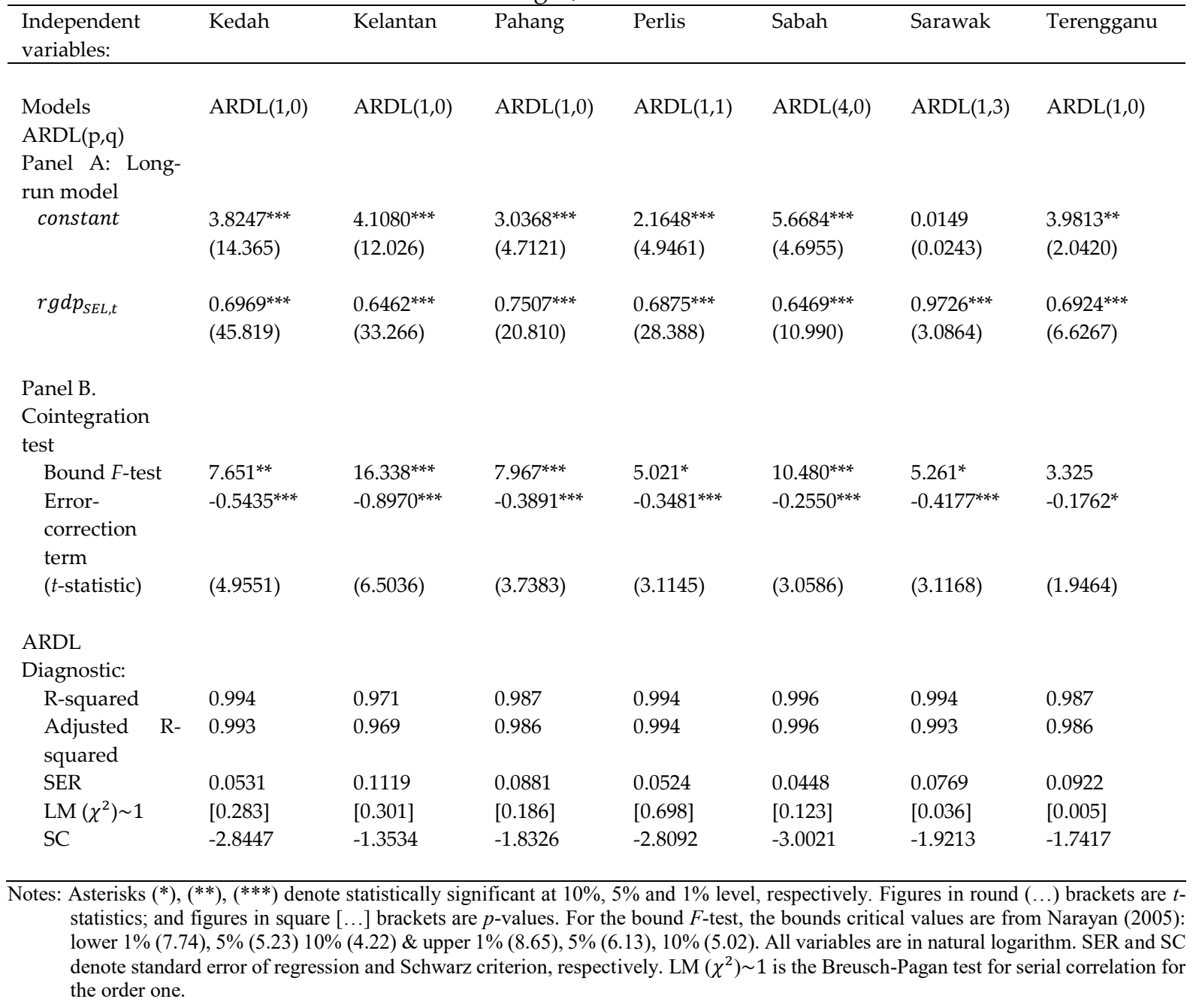


Table 4. Estimated long-run and short-run responses of less developed states to richer state -

Selangor, in per capita real GDP

\begin{tabular}{llllllll}
\hline $\begin{array}{l}\text { Independent } \\
\text { variables: }\end{array}$ & Kedah & Kelantan & Pahang & Perlis & Sabah & Sarawak & Terengganu \\
\hline $\begin{array}{l}\text { Models } \\
\text { ARDL(p,q) }\end{array}$ & ARDL(1,3) & ARDL(1,0) & ARDL(1,1) & ARDL(1,0) & ARDL(1,1) & ARDL(2,3) & ARDL(1,0) \\
$\begin{array}{l}\text { Panel A: Long- } \\
\text { run model }\end{array}$ & & & & & & & \\
$\quad$ constant & $-1.4433^{* * *}$ & -0.2036 & -0.8004 & $-2.0225^{* * *}$ & $3.5655^{* * *}$ & $-5.3696^{* * *}$ & -0.6551 \\
& $(4.9142)$ & $(0.5458)$ & $(1.6566)$ & $(4.3312)$ & $(8.5530)$ & $(3.7797)$ & $(0.4957)$ \\
& & & & & & & $1.0326^{* * *}$
\end{tabular}

Panel B.

\section{Cointegration}

test

\begin{tabular}{|c|c|c|c|c|c|c|c|}
\hline Bound F-test & $13.647^{* * *}$ & $21.970^{* * *}$ & $10.547^{* * *}$ & $6.128^{*}$ & 4.994 & 2.601 & 4.818 \\
\hline $\begin{array}{l}\text { Error- } \\
\text { correction } \\
\text { term }\end{array}$ & $-0.6498^{* * *}$ & $-0.9861^{* * *}$ & $-0.6043^{* * *}$ & $-0.3665^{* * *}$ & $-0.4206^{* * *}$ & $-0.1973^{* *}$ & $-0.2641^{* *}$ \\
\hline $\begin{array}{l}\text { (t-statistic) } \\
\text { RDL } \\
\text { iagnostic: }\end{array}$ & (5.1562) & (7.4700) & (4.5929) & $(4.6298)$ & $(3.1574)$ & $(2.2046)$ & $(2.6588)$ \\
\hline R-squared & 0.988 & 0.929 & 0.968 & 0.990 & 0.963 & 0.991 & 0.968 \\
\hline $\begin{array}{l}\text { Adjusted } R- \\
\text { squared }\end{array}$ & 0.986 & 0.926 & 0.965 & 0.990 & 0.960 & 0.989 & 0.967 \\
\hline SER & 0.0524 & 0.1045 & 0.0825 & 0.0484 & 0.0494 & 0.0710 & 0.0894 \\
\hline $\operatorname{LM}\left(\chi^{2}\right) \sim 1$ & [0.417] & {$[0.281]$} & [0.929] & {$[0.264]$} & {$[0.218]$} & [0.107] & {$[0.006]$} \\
\hline SC & -2.6878 & -1.4915 & -1.9013 & -3.0306 & -2.9261 & -2.0214 & -1.8032 \\
\hline
\end{tabular}

Notes: Asterisks $\left({ }^{*}\right),(* *),(* *)$ denote statistically significant at $10 \%, 5 \%$ and $1 \%$ level, respectively. Figures in round $(\ldots)$ brackets are $t$-statistics; and figures in square [...] brackets are $p$-values. For the bound $F$-test, the bounds critical values are from Narayan (2005): lower 1\% (7.74), 5\% (5.23) 10\% (4.22) \& upper 1\% (8.65), 5\% (6.13), 10\% (5.02). All variables are in natural logarithm. SER and SC denote standard error of regression and Schwarz criterion, respectively. LM $\left(\chi^{2}\right) \sim 1$ is the BreuschPagan test for serial correlation for the order one.

\section{Main Trends in Catching-up of the Less Developed States}

The cointegration test for convergence clearly suggests that the incomes of the less developed states are moving towards the income of Selangor. However, convergence does not answer the rates at which the less developed states catching-up to the richer state of Selangor. Halmai and Vasary (2010) argue that the pace of catching-up and convergence are not identical concepts: catching-up is the distance to be travelled, while convergence expresses the measure of progress. Halmai and Vasary (2010) propose the following catchup rate $(\mathrm{CR})$ as;

$$
C R_{H V}=100 \cdot \frac{\Delta\left(g d p_{i j t}-g d p_{i, S E L, t}\right)}{\left(g d p_{i j t-1}-g d p_{i, S E L, t-1}\right)}
$$


where $\Delta$ is the difference operator and all other variables are defined earlier. The catch-up rate is an indicator which measures the pace of catching-up to more developed states. In the case of negative catch-up rates disparity between states and Selangor is decreased and vice versa. However, according to Sopek (2013), the catch-up rate proposed earlier by Halmai and Vasary (2010) may not be the best measure of diminishing disparity. Sopek (2013) suggests the following modified catch-up rate,

$$
C R_{S}=100 \cdot \frac{g d p_{i j t}}{g d p_{i, S E L, t}}-\frac{g d p_{i j t-1}}{g d p_{i, S E L, t-1}}
$$

Opposite to Halmai and Vasary (2010) catch-up rate, $C R_{H V}$, the Sopek (2013) catch-up rate $C R_{S}$ suggests that disparity between the less developed states and Selangor is diminished in the case of positive difference of real GDP or per capita real GDP. Table 5 demonstrates the catch-up rates for the less developed states in Malaysia to the richer state of Selangor. On average, catch-up in growth of real GDP has not been narrowing for the past four decades. The only states experiencing diminishing disparity in terms of output with Selangor is Sarawak during the period 1981-2013 and 1991-2013, and Pahang during 20012013; while the rest of the less developed states showing widening disparity with Selangor. On the other hand, results for the catch-up rate in terms of per capita real GDP is more encouraging. Generally, all the less developed states except for Sabah showing diminishing disparity with the states of Selangor. For the period 1971-2013, the only states showing widening disparity with Selangor are Kedah and Sabah. The states of Pahang and Sarawak have shown diminishing disparity with the state of Selangor in all periods; 1971-2013, 19812013, 1991-2013 and 2001-2013. Nevertheless, on average, the less developed states are showing narrowing of income disparity with Selangor in all periods.

Table 5. Average catch-up rates for less developed states to Selangor, 1971-2013

\begin{tabular}{|c|c|c|c|c|}
\hline States & 1971-2013 & 1981-2013 & 1991-2013 & $2001-2013$ \\
\hline \multicolumn{5}{|c|}{ Panel A: Catch-up by growth in real GDP } \\
\hline Kedah & -0.70 & -0.48 & -0.31 & -0.20 \\
\hline Kelantan & -0.29 & -0.32 & -0.23 & -0.19 \\
\hline Pahang & -0.28 & -0.43 & -0.21 & 0.21 \\
\hline Perlis & -0.09 & -0.08 & -0.06 & -0.04 \\
\hline Sabah & -0.58 & -0.43 & -0.59 & -0.19 \\
\hline Sarawak & -0.33 & 0.22 & 0.10 & -0.18 \\
\hline Terengganu & -0.31 & -0.46 & -0.59 & -0.23 \\
\hline Average: & -0.37 & -0.28 & -0.27 & -0.12 \\
\hline \multicolumn{5}{|c|}{ Panel B: Catch-up by growth in per capita real GDP } \\
\hline Kedah & -0.02 & 0.04 & 0.22 & -0.08 \\
\hline Kelantan & 0.00 & -0.10 & 0.07 & -0.37 \\
\hline Pahang & 0.29 & 0.20 & 0.73 & 1.34 \\
\hline Perlis & 0.07 & 0.08 & 0.22 & -0.12 \\
\hline Sabah & -0.63 & -0.43 & -0.33 & -0.08 \\
\hline Sarawak & 1.14 & 1.84 & 1.88 & 0.34 \\
\hline Terengganu & 0.06 & -0.46 & -0.66 & -0.60 \\
\hline Average: & 0.13 & 0.17 & 0.30 & 0.06 \\
\hline
\end{tabular}




\section{CONCLUSION}

The last fifty years has made the state of Selangor the richest state in Malaysia in terms of gross domestic product. Selangor has benefited from the strategies and policies of the Malaysia's five-year plans and has able to attract investors to invest in the states. Unfortunately many other states in Malaysia are lagging behind in particular the less developed states of Kedah, Kelantan, Perlis, Pahang, Sabah and Terengganu; except for the state of Sarawak which has shown an amazing catching-up to Selangor.

In the present study, we investigate whether the less developed states has converge to the state of Selangor using the generalized one-step error-correction model for the period 1970-2013. We tested convergence on real GDP and per capita real GDP for the states involved and the results suggest that the less developed states has been converging to the state of Selangor for the period under study. In this study, we also determine the rates at which the less developed states catching-up to the richer state of Selangor. Generally, on average, the less developed states are showing narrowing of income disparity with Selangor in all periods.

In this respect, the state government has an important role to play in enhancing growth by continuously providing stable economic environment for investment and other productive economic activities. This will ensure full convergence can take place at a faster rate in the future. Narrowing the income gap between states in Malaysia will enhance economic integration with other ASEAN nations; to realize the aspiring ASEAN Economic Community; and a great booster for achieving the status of a develop nation.

\section{ACKNOWLEDGEMENTS}

Funding for this project comes from the Putra Grant (Grant No. GP-IPB/2014/9440901) provided by Universiti Putra Malaysia (UPM).

\section{REFERENCES}

Aslam, M. and Hassan, A.A.G. (2003). Development planning and regional imbalances in Malaysia. FEA Working Paper No. 2003-5. Faculty of Economics and Administration, University of Malaysia, Malaysia.

Bernard, A.B., and Durlauf, S.N. (1995). Convergence in international output. Journal of Applied Econometrics, $10,97-108$.

Bernard, A.B., and Durlauf, S.N. (1996). Interpreting tests of the convergence hypothesis. Journal of Econometrics, 71, 161-173.

Dickey, D.A. and Fuller, W.A. (1979). Distribution of the estimators for autoregressive time series with a unit root. Journal of the American Statistical Association, 74, 427-431.

Dickey, D.A. and Fuller, W.A. (1981). Likelihood ratio statistics for autoregressive time series with a unit root. Econometrica, 49, 1057-1077.

Ghani, J.A. (2014). Market preserving federalism: Implications for Malaysia. Unpublished PhD thesis. Victoria University, Australia.

Halmai, P. and Vasary, V. (2010). Real convergence in the new EU member states of the European Union (shorter and longer term prospects). The European Journal of Comparative Economics, 7(1), 229-253.

Leete, R. (2007). Malaysia: From Kampong to Twin Towers. Shah Alam: Oxford Fajar Sdn Bhd.

MacKinnon, J.G. (1996). Numerical distribution functions for unit root and cointegration tests. Journal of Applied Econometrics, 11, 601-618. 
Narayan, P.K. (2005). The saving and investment nexus for China: Evidence from cointegration tests. Applied Economics, 37, 1979-1990.

Pesaran, M.H., Shin, Y., and Smith, R.J. (2001). Bounds testing approaches to the analysis of level relationships. Journal of Applied Econometrics, 16, 289-326.

Roslan, A.H. (2008). The spatial distribution of poverty in Malaysia. Journal of Population and Social Studies, 17(1), 77-91.

Shamsulbahriah, K., Rodrigo, A. and Mansor, N. (2013). Narrowing disparities via the new economic model (NEM): Is Malaysia set to excel beyond its MDGs targets MDGs. In A. Singh, E.T. Gonzalez and S.B. Thomson (Eds.). Millennium Development Goals and Community Initiatives in the Asia Pacific. New Delhi: Springer India. pp. 11-33.

Shari, I. (2000). Economic growth and income inequality in Malaysia, 1971-95. Journal of the Asia Pacific Economy, $5(1 / 2), 112-124$.

Sundaram, J.K. and Hui, W.C. (2014). Malaysia@50: Economic Development, Distribution, Disparities. Petaling Jaya: Strategic Information and Research Development Centre.

Sopek, P. (2013). Real convergence of EU-27 and Croatia in the period 1995-2017. Paper presented at The 8th Young Economists' Seminar to $19^{\text {th }}$ Dubrovnik Conference. Organised by Croatian National Bank. Dubrovnik. June 12, 2013. 